\title{
聴覚障がいをもつ薬学生に対する実務実習事前実習の構築と当該学生の意識調査
}

\author{
眞島 崇, ${ }^{a}$ 早坂正孝, ${ }^{b}$ 大原宏司 ${ }^{*}, b$
}

\section{Construction of Pre-clinical Practice and Survey of Consciousness for Pharmacy Students with Hearing Disability}

\begin{abstract}
Takashi Majima, ${ }^{a}$ Masataka Hayasaka, ${ }^{b}$ and Hiroshi Ohara ${ }^{*}, b$
${ }^{a}$ Department of Pharmacy Practice and Pharmaceutical Sciences, Faculty of Pharmaceutical Sciences, Setsunan University;

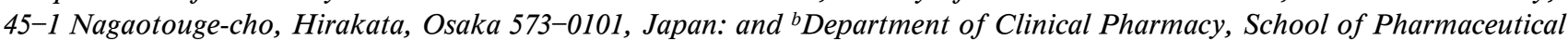
Sciences, Ohu University; 31-1 Misumido, Tomitamachi-aza, Koriyama, Fukushima 963-8611, Japan.
\end{abstract}

(Received December 18, 2020; Accepted May 29, 2021)

\begin{abstract}
Various types of pre-learning - including pre-learning for practical training - provide pharmacy students with practical training and sufficient knowledge, skills, and attitudes for practical work. Opportunities in the medical field, including for pharmacists, have been greatly expanded for students with a hearing disability, and we have responded with appropriate training for such students. In this study, we report on the results of an evaluation of a survey on the preparatory training conducted by the students and the changes in their consciousness, such as in their level of understanding, knowledge, and self-confidence. Before the training, the participants' anxiety concerning items related to dispensing and communication were quite high; after the training, however, these anxiety levels were reduced. In addition, we were able to encourage the participant's concern for people and to face the difficulty of expressing words in letters, as well as to drive enthusiasm for the Objective Structured Clinical Examination (OSCE) and practical training. These results suggest that having a teacher as an assistant is useful for helping students with hearing disability in practical training.
\end{abstract}

Key words — - hearing disability; pre-learning; self-confidence; self-efficacy

\section{緒 言}

わが国の聴覚障がい学生支援の背景には，文部省 が「昭和 49 年度大学入学者選抜実施要綱」に初め て身体障がい者の受験機会の確保に関する一文を掲 載し, 1,2) 障害の種類・程度により配慮する具体例を 明示したことに始まり, ${ }^{3)} 1975$ 年, 日本学術会議の 勧告「社会福祉の研究・教育体制等について」の中 で身体障がい者の大学受け入れに関する対策を講じ るよう指摘がなされた。こうした動きを受け，各大 学で障がい者における教育環境が整備されつつあつ た. ${ }^{4}$ 奥羽大学薬学部（以下, 本学) においても聴 覚に障がいをもつ学生（以下，当該学生）が就学し た. 6 年制薬学教育カリキュラムでは，臨床に係る 実践的な能力を培うことを主たる目的と掲げており, 5 年次生において実臨床での実務実習が義務化され

$a$ 摂南大学薬学部実践薬学分野, $b$ 奥羽大学薬学部医療 薬学分野

*e-mail: h-ohara@pha.ohu-u.ac.jp
ているが, 薬学生の質的保証は技能・態度を評価す る客観的臨床能力試験 (Objective Structured Clinical Examination; OSCE) の合格水準に達すること が必須となる.よって，4 年次生における病院・薬 局実務実習事前実習（以下，事前実習）は重要な位 置を占める. 5,6$)$ 事前実習では各調剂実習を始め, 模 擬患者・医師とのコミュニケーショントレーニング を含むが，当該学生は $105 \mathrm{~dB}$ 以上の音を感知でき ない重度難聴であり, 手話や読話での意思疎通も困 難であった，そのため当該学生に聴者と同じ学習効 果をもたらす学習環境の保障が議論されたが, どの ような支援が必要か, 本学で前例がないことや大学 内外でどれだけの協力を確保できるか等, 課題が多 い実情にあった。

そこで本研究は，筆者らが当該学生の実習パート ナーとなり, 実習に際しての障壁や実習内容の理解 度を観察し, 当該学生に必要な支援を把握すること が重要と考え, 事前実習の評価とその理解度, 習得 度及び自信等の意識変化を調査することで, 当該学 生によりよい学習環境の整備を図ること，併せて当 
該学生が参加型の実務実習を実践するための自発的 能力の啓発を目的とした.

\section{方法}

事前実習に先立ち, 当該学生の不安や問題点の抽 出及び OSCE における特別措置の申請を目的とし て，聴覚障害者支援委員会（以下，支援委員会）を 発足し，障害の程度や実習に対する障壁等について 事前調査を行った。本学では合理的配慮の観点か ら，支援委員会は教員，カウンセラー及び大学事務 で構成され，事前実習や OSCE に必要な教育体制 と薬学共用試験センターに対する特別措置の申請を 行った. 事前調査により, 当該学生は重度難聴に相 当し，リアルタイムな伝達なしでは事前実習の遂行 は難しい状況であった。意思疎通の有効な手段とし て，手話，発語及び読話が挙げられるが，当該学生 は筆談以外の伝達技術を習得していなかった。 そこ で，本学教員が実習パートナーとなり筆談を主な伝 達手段として，また，「課題をはじめてください」 等の定型事項の伝達にはプラカードを活用し，とき に実演，ボディランゲージ（握手・ハイタッチ）や ハンドサイン（OK サイン）等を用い学習支援にあ たつた，当該学生への情報保障を目的として，意思 疎通を図る際はかならずボディタッチを交え随時内 容の確認を行い理解度の向上につなげるため事前実 習終了ごとに筆談記録等をすべて手渡した.

当該学生の事前実習に対する評価，理解度及び自 信等の意識調査は, 実習前 1 回（薬局実習前アン ケート), 実習中 2 回(薬局実習終了後アンケート・ 病院実習前アンケート）及び実習後 1 回, 計数・計 量・注射調剂及び患者応対等の項目について実施し た（Table 1）。実習中 2 回のアンケートは同日に実 施したため，まとめて 1 回として集計した。得られ た結果は，「事前実習の経過に伴う不安の変化及び 改善」「事前実習に係る教員に対する評価」，「事前 実習進行に伴う理解度」，「OSCE・実務実習に対す る自信」の 5 項目について「5 非常にそう思う〜 1 全くそう思わない」，「5十分に理解できた〜1 全く 理解できなかつた」の 5 段階評価の推移と自由記載 内容で解析した。なお，調査時点における実習未実 施部分を「一」, 調査対象外 (OSCE の対象外) の 実習項目を「***」とした（Table 1).

倫理的配慮 本研究は, 平成 25 年度本学倫理
審査委員会の承認（承認番号：85）を得て行つた. 事前実習開始前に当該学生と家族に対して本調査の 趣旨について説明し，学会等で発表される可能性が あること，個人情報が外部に公表されることはない が，研究の性質上個人を特定できてしまう可能性が あることを伝えたうえで同意を得て実施した．結果 の論文公表については，平成 28 年度奥羽大学（承 認番号：156 号）及び摂南大学（承認番号： 2016-072）各倫理審査委員会の承認を得た後，当該 学生と家族に学術論文にて発表する可能性について 説明し，同意を得た。

結果

当該学生に対して実施したアンケート内容とその 結果を Table 1 に示す。事前実習「前」アンケート Q1 の「事前実習を行うにあたって不安なことはあ りますか?」に対し，「非常にそう思う」に該当す る 5 を選択した。同様に調剤実習及び患者応対終了 後の事前実習「中」アンケートQ1の「事前実習を 経験して不安なことはありますか?」においても強 い不安度を示す 4 及び 5 を選択したが，事前実習終 了「後」アンケート Q1 の「事前実習を終了しまし たが不安はありますか?」に対し，「全くそう思わ ない」，「そう思わない」に該当する 1 及び 2 を選択 した.

実習中アンケート Q2 の「事前実習が進む中で不 安は改善されましたか?」に対し, 当該学生は「や やそう思う」に該当する 4 を選択し，実習後アン ケートQ2「事前学習が終了して不安は改善されま したか?」に対し，すべて 4 以上を選択した．不安 に関する自由記載項目の推移は，実習前アンケート では「口で話すことや，患者情報を聞き取る作業が 難しい」と記載し，実習中アンケートでは，「ロー ルプレイは他の人より時間がかかってしまい, どう すればいいのでしょうか?」との記載があった．実 習後アンケートでは，「何回か練習をさせてもらつ たり，実習中に先生方に注意点や説明などを詳しく して頂いたりしたので，スムーズにできるように なった」と記載があった.

実習後アンケート Q3 の「事前実習全体を通じて 実習の内容は理解できましたか?」に対し，当該学 生は「まあ理解できた」に該当する 4 以上を選択し た。実習後アンケートQ4 の「事前実習全体を通じ 
Table 1. Questionnaire Items and Answers about the Pre-clinical Practice

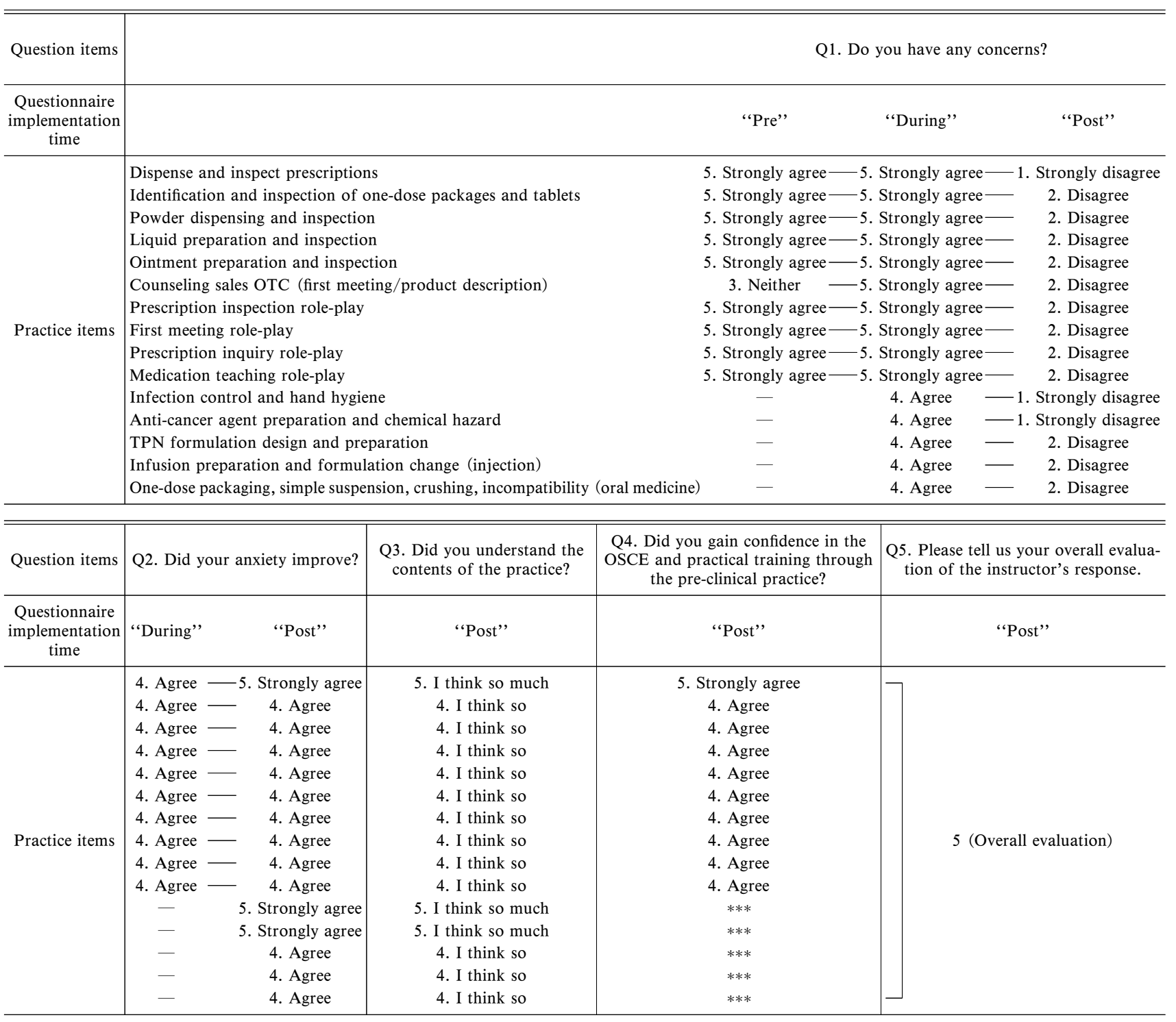

Changes in free description throughout the pre-clinical practice period.

$$
\text { "Pre" "During", }
$$

Evaluation $\quad$ "It is difficult to speak and listen to a patient's
information at the same time."
"'Role-play takes longer than others; what
should I do?"
"Prescription inquiries are asked over the
phone, but it is challenging to explain over the
phone; what should I do?"

Comprehension "It is difficult to speak and listen to patient's information at the same time."
"It took a long time because it was not done smoothly.", 
て OSCE や実務実習に対する自信がつきました か?」に対し，「ややそう思う」に該当する 4 以上 を選択した。 また，実習後アンケートQ5の「事前 実習全体について，指導教員の対応に関してあなた の総合評価を教えてください」では 5 段階評価の最 高点 5 の記載があり，自由記載では，「何回か練習 をさせてもらったり，実習中に先生方に注意点や説 明などを詳しくして頂いたりしたので，スムーズに できるようになつた」や「トレーニング中に詳細に 教えたり，私と一緒に練習したりするなど，適切な 指導をありがとうございました」との記載があった.

\section{考察}

当該学生への事前調査により，障害の程度，不 安, 必要な支援及び求める情報保障についての共通 認識を図ることができた。アンケート結果より，事 前実習の経過に伴う不安度が低下する傾向が認めら れた，実習前は「口で話すと同時に聞き取る作業が 難しい」と述べていたが，終了後では「伝えたい言 葉を全て文字で表わすのはとても大変なことで，難 しいことだったと思う」に変化し，コミュニケー ション能力を培うことの重要性やその困難さへの理 解が示唆された。また，「何回か練習をさせても らったり，実習中に先生方に注意点や説明などを詳 しくして頂いたりしたので，スムーズにできるよう になった」との記載から，教員に対する評価や習得 度の向上を示唆する文言が見受けられた（Table 1)。こうした自由記載内容からも，事前実習の経過 に伴い当該学生が調剂技術，コミュニケーションを 始め，OSCE や実務実習に対して自信を深める傾向 が示唆された。

本事例は，本学薬学部にとつて初の取り組みであ る. 他方, 全国の医学部では聴覚障がい学生が在籍 している. ${ }^{7)}$ 大鹿らは, 聴覚障がいをもつ学習者の 困難が自身の聞こえ難さに由来するのか，環境に由 来するのか，その区別や所在に関する支援者側の認

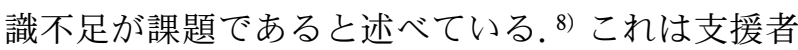
が過去・現在の状況からどのような支援が必要かを 検討することで解消可能と考え，当該学生が「聴覚 障害に起因する学習困難を克服し OSCE や実務実 習への自信を獲得する」という目標を達成できるか が争点となった，和田らは，聴覚障がい学生のス ムーズな支援のための要素として「1教育・指導・
支援する側の強力なリーダーシップ」，「(2)細やかな 連絡体制」及び「(3)本人との信頼関係」の 3 要素が 重要な鍵になるとしている. ${ }^{5)}$ 当該学生の支援にお いて，(1)に関して，筆者らが一教員としてだけでな く, 支援委員として必要と思われる教育法を模索し た。当初，声を文字に変換する音声認識技術の導入 を試みたものの，特定の声を認識できないことや変 換能力の限界もあり，筆者らが実習パートナーとし て筆談等を介してリアルタイムに伝達した，本法を 他の教員や学生に波及させることで，周囲からサ ポートを得られる体制を整えた。(2)に関して，事前 実習担当教員と綿密な情報交換を行うことで，当該 学生が困難と感じる調剤技術，模擬患者・医師への 応対について詳細かつ適切なフィードバックが可能 となった。 (3)において，当該学生の不安や悩みを抽 出し，支援委員会と協議のうえ補習又は精神的サ ポートを試夕た。また，健康状態について保護者や 支援委員会へ報告・相談を行い，心身に無理のない 学習環境の整備に努めた。一方，当該学生との考え 方の違いから実習を中断せざるを得ない状況に至る 場合もあったが，事前実習終了まで実習パートナー を変更することなく遂行し得たことは，当該学生と の信頼関係に由来するものと考えている．菊地と安 原は障がいをもつ学生支援の有機的な連携のために は，状況や状態に適した能力を有すキーパーソンを 見い出すことが重要であると述べている. ${ }^{9)}$ 以前, 筆者らは他職種間の相互理解が自己効力感を向上さ せる可能性があることを報告した. ${ }^{10)}$ 支援体制を構 築するうえで，他職種で構成される支援委員会が発 足し，事前実習の推進を後押しした．本学のケース のように教員がパートナーとして理解と習得をサ ポートし，支援委員会とともに当該学生の不安に焦 点を当てたインクルージョンな支援方略は，当該学 生にとって効果的な情報提供法 (筆談)を見い出し, 自身の障害・特性を把握したうえでのスキルアップ を可能にしたことから，調剂技術やコミュニケー ション能力の醸成を始め, 当該学生の情報保障を支 援できたと考えている.

当該学生は，OSCE に合格し実務実習に進むこと ができた。本学では，支援委員会が地域薬剤師会と 協議し，合理的配慮の下，健常学生と同等の実務実 習を達成できるようサポート可能な体制を整備し た。しかしながら，薬学教育における本事例のよう 
な報告は少ないことから，聴覚障がいをもつ薬学生 を支援する活動はいまだ途上にある．特別措置が必 要な薬学生に対するサポート体制の構築と自己効力 感の向上において，一例ではあるが筆者らの経験が 今後の薬学教育の一助となれば本望である.

謝辞事前実習の実施にあたり，多大なるご支 援を賜りました聴覚障害者支援委員会及び同大 5 年 次生の皆様に深く感謝申し上げます。

利益相反 開示すべき利益相反はない.

\section{REFERENCES}

1) Kawauchi K., Jpn. Assoc. Spec. Educ., 39, 33-45 (2002).

2) Tsuzuki S., Iris health, 13, 25-31 (2014).

3) Ministry of Education, Culture, Sports, Science and Technology. "Changes in the Treatment of Persons with Disabilities in the
Guidelines for University Enrollment Selection."':〈https://www.mext.go.jp/component /a_menu/education/detail/__icsFiles / afield file/2012/12/06/1328142_3.pdf $\rangle$, cited 19 November, 2020.

4) Urabe N., Iwata Y., Bulletin of Special Education and Welfare, 7, 17-24 (2011).

5) Wada T., Hirose Y., Nishimura B., Hoshino T., Uemaetomari I., Tabuchi K., Okubo H., Hara A., Audiol. Jpn., 55, 61-67 (2012) .

6) Kiuchi Y., J. Drug Deliv. Sci. Technol., 65, 331-333 (2005).

7) Ohishi T., Nakao M., Yano E., Med. Educ., 38, 285-288 (2007).

8) Oshika A., Hamada T., Jpn. J. Hear. Lang. Disord., 35, 119-126 (2006) .

9) Kikuchi C., Yasuhara T., Jpn. J. Pharm. Educ., 2, 1-8 (2018).

10) Majima T., Ohara H., Yakugaku Zasshi, 138, 251-258 (2018). 